\title{
ニューラルネットワークを用いた網目ドームの弾塑性解析結果の知識処理 KNOWLEDGE BASED CASE STUDY ON CREATING AN EXPERT SYSTEM TO PREDICT BUCKLING BEHAVIORS OF RETICULAR DOMES USING NEURAL NETWORK TECHNICS
}

\author{
高島 英幸* \\ Hideyuki TAKASHIMA
}

\begin{abstract}
Soft computing technics have often been used in various engineering fields. A neural network, one of them, has also been noticed as one of powerful approaches that can solve complicated problems.

The present research deals with that how to utilize accumulated results being yielded from structural numerical simulations or experimental tests. The neural network has a potentiality to store them without a huge space in the knowledge base system. The neural network can also interpolate the descrete results with respect to given data, linearly or non-linearly. Furthermore, the availablity for a reasoning engine in the expert system is also investigated. The system would be so available for all designers, when the method to extract easily the digitized certain knowledges was established.

As the example, the elastio-plastic buckling behaviors of single layered reticular domes whose behaviors have to be estimated with many structural parameters, are treated.

Through several case studies, the performances of the neural network are discussed.
\end{abstract}

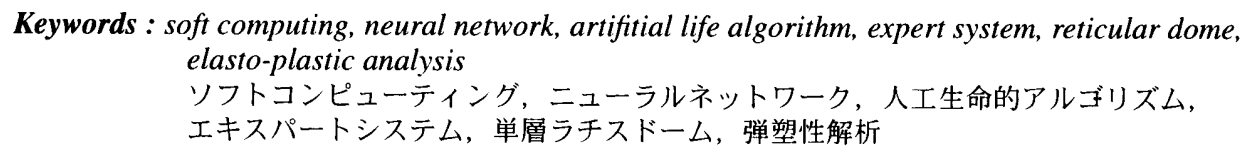

1. 序

ニューラルネットワーク $(\mathrm{NN}) ，$ 遺伝的アルゴリズム $(\mathrm{GA})$ を始め とする人工生命を模したアルゴリズム(Soft Computing)の利用は建 築分野でも構造部材の復元力・振動同定から最適構造形態の模索,

都市計画，防災計画など多岐に渡って研究されている(例えば文献 1)などを参照されたい)。NNに関しては，その適用範囲，新たな計 算手法の模索が連綿と行われており(文献2)４）など), 研究分野も 比較的幅広い。建築構造分野に関わる具体例は下に挙げるが，その 多岥に渡る適用性を更に追求する目的で，構造設計支援システム内 の推論エンジンへ NNを応用することを本論文では試みる。具体的 には，その適用性を建築構造に関わる単純な例題から検討し，網目 状単層ラチスドームの解析結果をSoft Computingの手法を用いるこ とで，より複雑な解析過程を踏むことなく，専門家が判断するよう に構造挙動を提示できないかという点を検討していく。尚，GA等 を用いた戦略の提案, サーベイは本論文に続く NNのパラメー夕選 択問題を取り上げる中で行う予定である。

NNの研究は1958年の Rosenblattによるパーセプトロンの提案 5) が最初期と考えられ，その後， Minsky， Papert によってパーセプ トロンの能力を詳細検討し限界を示した研究 ${ }^{6)}$ がまとめられた。 ネットワークとしての学習機能を確立させたのは1986年の Rumel-

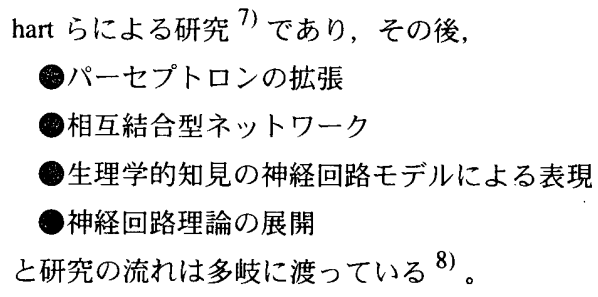

構造工学の分野へのNNの応用は，Ghaboussi ら ${ }^{9)}$ あるいは吉村 らの構造部材の履歷モデルのシミュレートに関する研究 ${ }^{10)}$ から始 まり，建築構造分野における適用例も現在ではある程度の蓄積が進 んでいる。建築分野では, 堤, 河村, 谷の構造計画支援に関する研 究 ${ }^{11)}$, 谷, 河村の構造物の地震時制御に関する研究 ${ }^{12)}$ が先駆之言 える。更に，地震応答の推定に適用した水野ら ${ }^{13)}$ ，楊ら ${ }^{14)}$ の研 究, 地震検知システムの応用を試みた神田の研究 ${ }^{15)}$, そして, 堤 らにより地震応答の予測システム, あるいは骨組構造物の設計シス

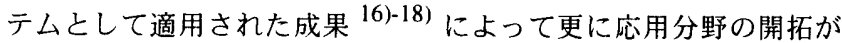
行われてきた。最近では原点回帰的に構造システムの履歴モデルへ の応用 ${ }^{19), 20)}$ も展開されている。

本研究の最終的な目的は，鉄骨単層状スペースフレームの弾塑性 挙動の知識整理を行ない，それを元に設計支援システムを構築し， 専門家知識が活用できる環境を提供することにある。それに際し， 
データベース，あるいはエキスパートシステムの推論エンジンの確 立にあたって, データの再現能力とデータ補間能力を有し, 適用範 囲の柔軟さに注目し，NNを手法として取り上げた。研究目的遂行 にあたり，本論では，その初期段階として，著者が行なってきた $F$ E M による単層状ラチスドームを構成するユニットパネル (後出の 図ー4のドーム内太実線部参照)」の弾塑性座屈解析結果 ${ }^{21)}$ を元 に, 耐荷力, 崩壊モードなどを知識ベースとして整理し, 設計時工 キスパートシステムの推論エンジンの基礎を築くことを試行する。 具体的には，その構造挙動を模擬する方法あるいは知識データベ一 スとしての， NNのデー夕再現性や補間性能を検討することにな る。このようなNNの構築は, 例えば, IF〜THENで表記されるプ ロダクションルールの知識表現と同等であり, 且つ補間的なルール まで含有するものとなり得よう。

\section{NNによる単柱の座屈曲線の模擬}

2.1 目的

NNの特性・限界を把握しておくために，比較的単純な事象をど の程度まで模擬出来るのかを検討しておく。階層型NNの典型的な 構成を図- 1 に示す。対象は単柱の座屈曲線関数で, 限界細長比を 境にJohnson式とEuler式が共存するものを考える。従来は 2 つの式 で表現されることになるが，NNであれば1つの単純なシステムと して表現できる。模擬する座屈応力度 $\sigma_{c r}$ は,

$$
\sigma_{c r}=\left\{\begin{array}{l}
\pi^{2} E / \lambda^{2}(\lambda>\Lambda) \\
\left.\left./ 1-0.4(\lambda / \Lambda)^{2}\right)\right\} \sigma_{y} \quad(\lambda \leq \Lambda)
\end{array}\right.
$$

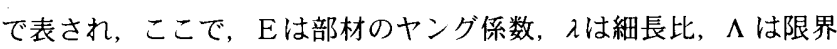
細長比， $\sigma_{y}$ は降伏応力度である。

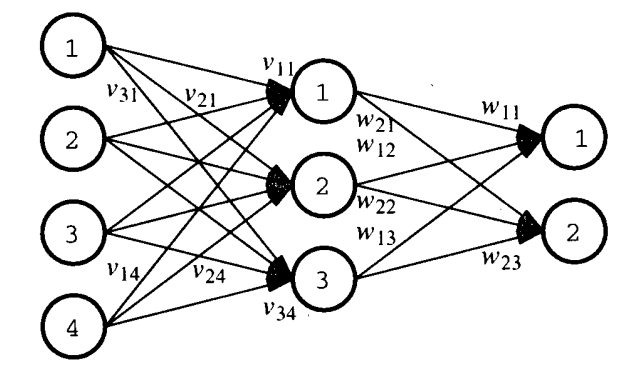

SENSORY ASSOCIATIVE RESPONSE

図ー 1 ノード間の連結係数とネットワークの典型的構成

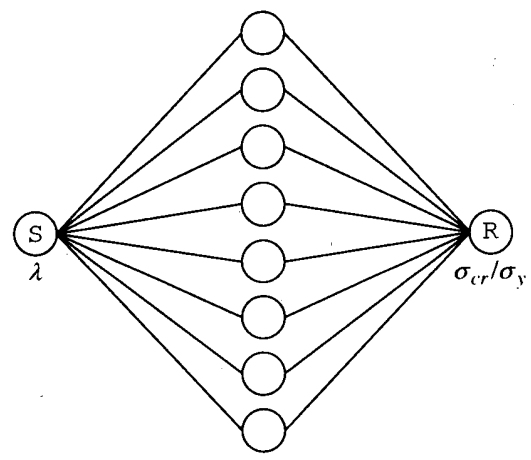

図ー2. 単材の座屈曲線に対して採用されたネットワーク

2.2 採用したネットワークと基礎式
$\mathrm{NN}$ は図ー 2 にあるように，入力層に1ノード，中間層に 8 ノー ド，出力層に1ノードを配置した。最も単純な構成として，入力に 細長比を出力に座屈応力度を当てはめ, 中間層は仮に 1 層のみとし て試行を行った。中間層の数とそれを構成する節点数はシステムの 複雑性に依存する部分があり，試行錯誤的に変化させ，模擬対象を 表せるか否かを検討していく必要がある。

教師データは細長比 10〜200迄を等間隔にして, 座屈応力度と組 にして合計10,15,20個を与えた。教師データ数Nに対するシステム の敏感度を検討するためである。

$\mathrm{j}$ 節点への入力 $x_{j}$ は, その 1 つ前の層の $\mathrm{i}$ 節点からの出力 $y_{i}, j, \mathrm{i}$ 節点間の結合強さ $($ 係数 $) w_{j i}$, オフセット $\theta_{j}$ により,

$$
x_{j}=\sum_{i} y_{i} \cdot w_{j i}+\theta_{j}
$$

と表される。入力 $x_{j}$ と, その節点からの出力 $y_{j}$ の関係は次式で示 す sigmoid関数で仮定した。

$$
y_{j}=\frac{1}{1+e^{-x_{j} \cdot \mu_{17}}}
$$

システムに比較的大きな影響を与えるパラメータとしては，ネット ワークの形もさることながら, 各節点で入出力される数値を産み出 す関数も重要視される。式(3)に示すsigmoid関数の傾きを表すパラ メータ $\mu_{0}$ がその代表的なもので, 式(2),(3)にNNの基礎式として提 示した。収束性能に影響を与えるものとしては節点間の結合係数を 変化させていく際の增分量も考えられよう。レスポンス層の $\mathrm{j}$ 節点 のエラー值は $\mathrm{j}$ 節点の教師データを $T_{j}$ とすれば,

$$
E=\frac{1}{2} \sum_{j}\left(y_{j}-T_{j}\right)^{2}
$$

で評価できる。各層における結合係数 $w_{j i}$ に関する勾配は,

$$
\frac{\partial E}{\partial w_{j i}}=\left(y_{j}-T_{j}\right) \cdot y_{j}\left(1-y_{j}\right) \cdot y_{i}
$$

であるから， $w_{j i}$ の修正量 $\Delta w_{. j i}$ は加速度法を採用することによって 次式で求められる。

$$
\Delta w_{j i}=-\alpha \frac{\partial E}{\partial w_{j i}}(t)+\Delta m \cdot \Delta w_{j i}(t-1)
$$

ここで， $\alpha$ が収束計算用の増分量, $\mathrm{t}$ は収束ステップを表す。修正 された $w_{j i}$ を用いてEを計算し，規定值以下になるまで収束ステッ プを繰り返す。本NNでは節点にオフセット $\theta_{j}$ が組み込まれている が，上述と同様の方法で収斂計算を行なうことが可能であり，式 (6)中の $\alpha$ を湢き換え， $w_{j i}$ を $\theta_{j}$ と読み替える。

本例題を通して得られた，これらのパラメータと構築したネットワ 一クの挙動の関係を次節に纏めておく。

2.3 シミュレート結果と考察

結果については一部を文献 ${ }^{23)}$ において示しているが, 改めて纆 めておくと,

(1) NNの各種パラメータは図ー3にあるように結合係数の增分量 $\alpha$,オフセットの增分量 $\beta$, sigmoid関数の傾き $\mu_{0}$ を決定した。 各量を変化させる試行錯誤が必要となる。

(2) 補間性能は今回設定した教師データの数で優劣を認められる程 の差は確認できなかった。 


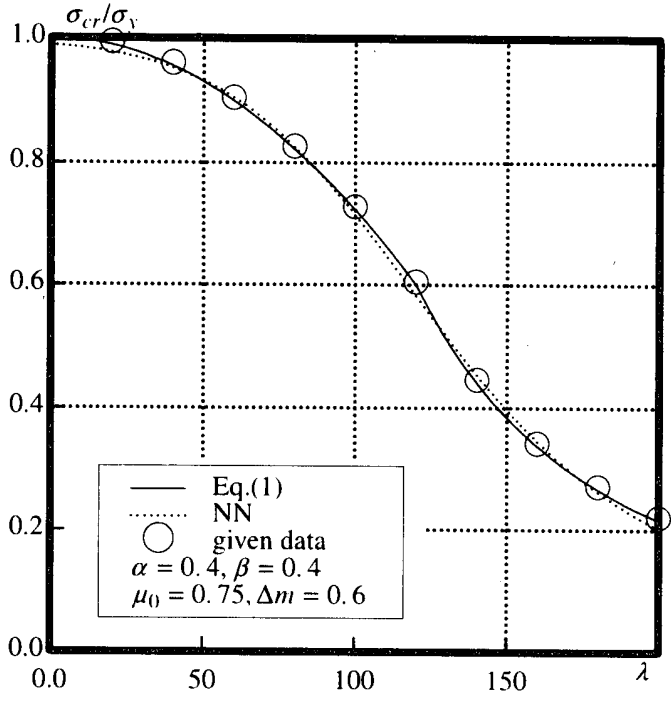

図一 3 Euler/Johnson座屈曲線の模擬
(3) 図-4は学習デー夕数 $\mathrm{N}$ と外挿性能の変化を呈示している。 外挿性能については教師デー夕間を最終的にsigmoid関数が補 間していることからその形態がそのまま反映されてしまうの で, 補間精度をあげることで若干性能の向上が認められるも のの, 信頼性は十分とは判断出来ず, システムに十分な外挿 性能を要求することは困難だと思われる渄1》。

\section{3. 単層ラチスドームの座屈荷重, パターンの知識化}

著者らが解析してきた6角形平面3方向格子単層ラチスドーム( 図-4)の弾塑性解析結果を知識として，NNを利用した推論シス テムの構築可能性を検討する。対象としたラチスドームは著者ら が既報 ${ }^{21)}$ で取り上げたものでボール接合を想定した部材モデル 化まで行われている。コンピュータの急速なCPU速度の向上によ り計算効率は飛躍的に高くなったが，弾塑性座屈モードを試行錯 誤的に選定し非線形解析を進める場合も多く，挙動追跡と結果の 分析には依然として時間を要する。従って，一度シミュレーショ ンを実行し得られた結果は適時再閲覧，あるいはそれらを用いた 比較的精度良い予測ができるようシステム化して置くことで, 新 たなシミュレーションを実行する際，または類似構造物の設計時 に有用であると考えられる。

3.1 単位ドームに対する試行

\subsection{1 対象}

まず図ー4において太い実線で示される部材を周辺に持つ単位 ドームの頂点の鈶直方向座屈荷重と座屈タイプを対象にNNによ る知識化を試みた。座屈タイプは単位ドームの場合, 部材座屈 と，頂点節点の鋁直変位が卓越するディンプル座屈の 2 種類に大 別できるため，前者を 0 とし，後者を 1 とバイナリ表現して教師 データを作成した。境界条件はドーム周辺節点がピン支持となる か，ドーム中央から放射状ローラ一支持されるかの 2 種類として いる。一方，NNの構成は入出力デー夕と共に図ー 5 に示してい る。尚，入出力データには表－1のように正規化を施している。 表中， output 2 にある座屈タイプの出力が 2 取り得るようにある が，これはドーム全体が鈶直下方へ変形する全体座屈を分類した もので $n=4$ のケースで用いられ，単位ドームには用いない。

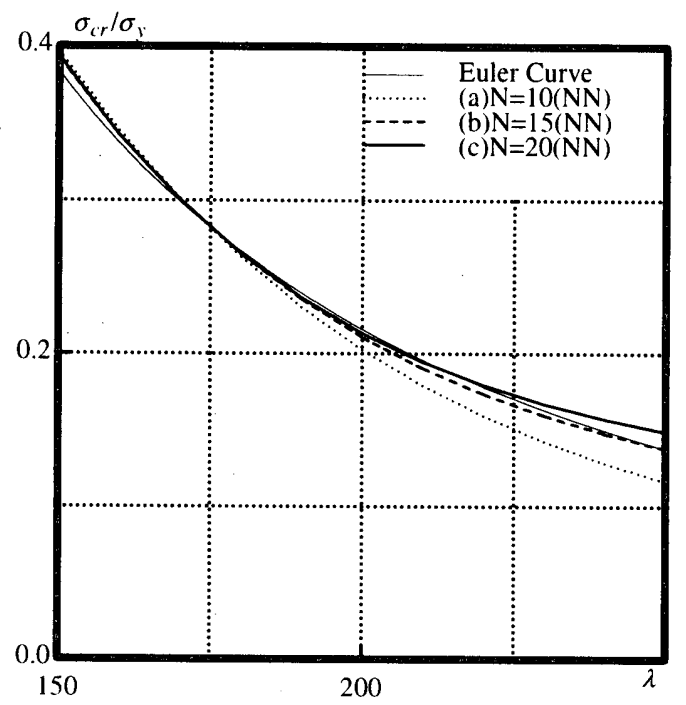

図 -4 外挿の精度 $\lambda>200$ の範囲の検討

入力データはドームの形状, 境界条件に関するものと構成する部 材の材料特性に関するものとしているが, この他, 荷重状態, 初 期不整などの情報もシステムの充実化には必要になろう。

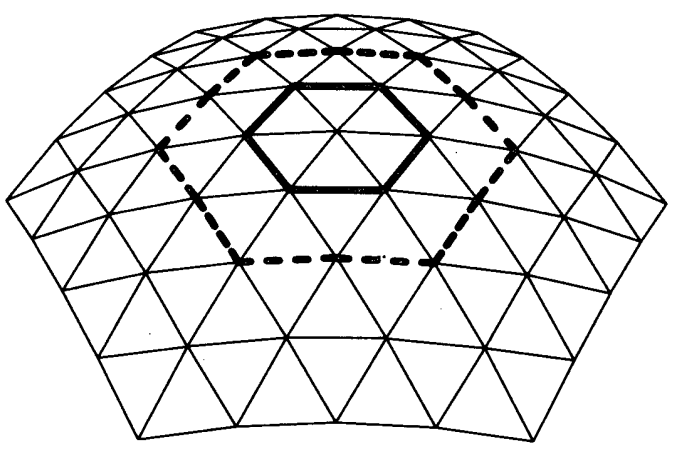

\begin{tabular}{|l||c|}
\hline slenderness ratio $\lambda$ & $60,96.21$ \\
\hline$\phi_{0}$ & $2,2.5,3,3.5,4^{\circ}$ \\
\hline connection & pin, semi-rigid, rigid \\
\hline$I_{p}, I_{c}$ & $395.47,11.46 \mathrm{~cm}^{4}$ \\
\hline$\sigma_{y}^{p}, \sigma_{y}^{c}$ & $2.4,2.7 t f / \mathrm{cm}^{2}$ \\
\hline support & pin, roller \\
\hline number of spans:n & 2,4 \\
\hline
\end{tabular}

$I_{c}$ :moment of inertia of connector, $I_{p}$ :moment of inertia of pipe $\sigma_{y}^{p}$ :yield stress of pipe, $\quad \sigma_{y}^{c}$ :yield stress of connector

図ー4 対象としたドームと構造パラメータ

表一 1 入出力データの正規化

\begin{tabular}{|l||c|c|c|c|}
\hline unit & 1 & 2 & 3 & 4 \\
\hline input & $\lambda / 200$ & $\phi_{0} / 10$ & $\sigma_{y}^{p} / 10$ & $\sigma_{y}^{c} / 10$ \\
\hline \hline unit & 5 & \multicolumn{2}{|c|}{6} & 7 \\
\hline input & $I_{c} / I_{p}$ & pin sup.: 1/rol. sup.:0 & $n / 20$ \\
\hline
\end{tabular}

\begin{tabular}{|l|l||l|l|} 
output 1 & $\operatorname{Pcr}(t f) / 20$ & output 2 & buckling type $(0,1,2) / 2$ \\
\hline
\end{tabular} 


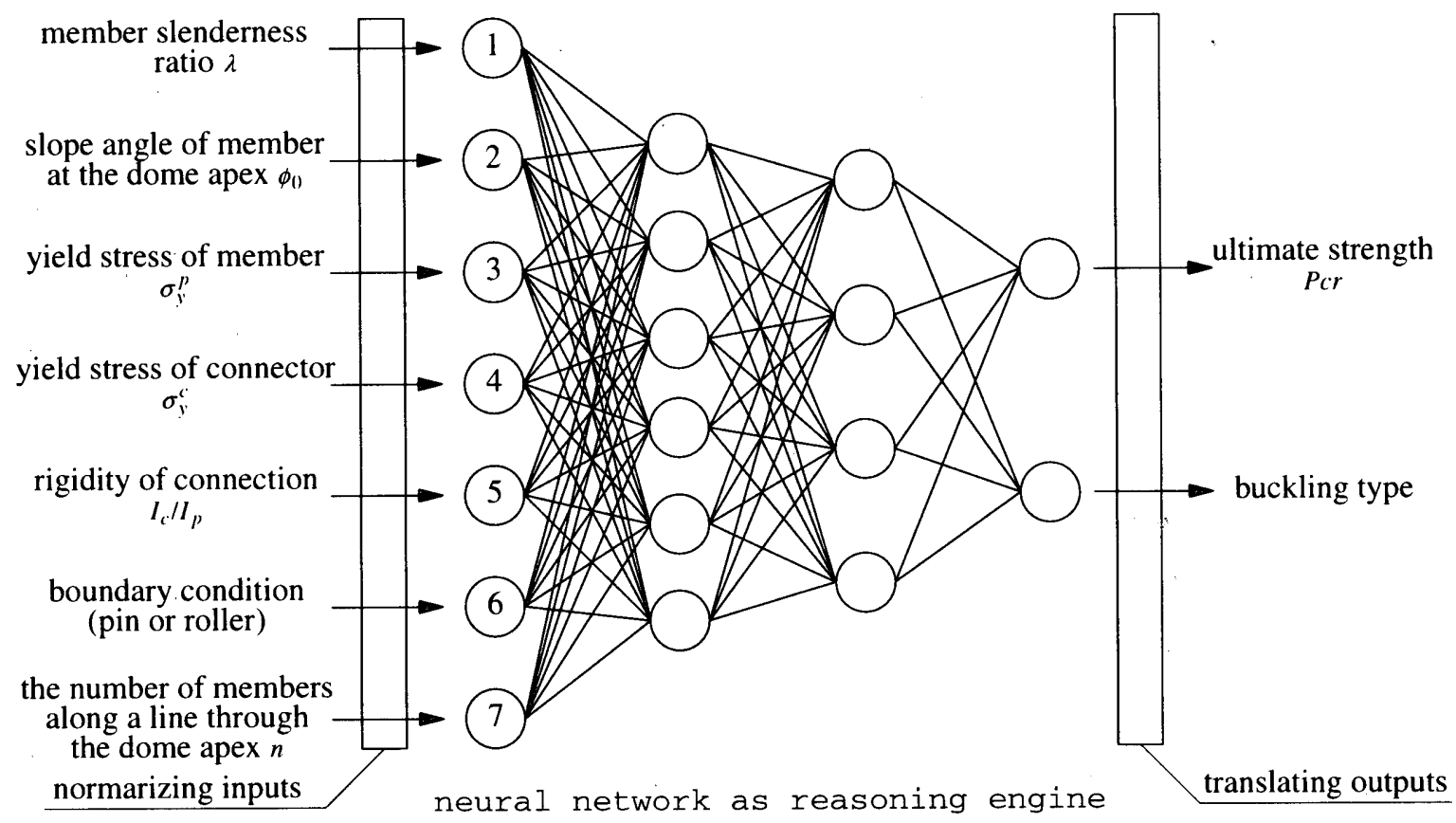

図ー5 単層ラチスドームの弾塑性挙動表現用に構築したニューラルネットワーク

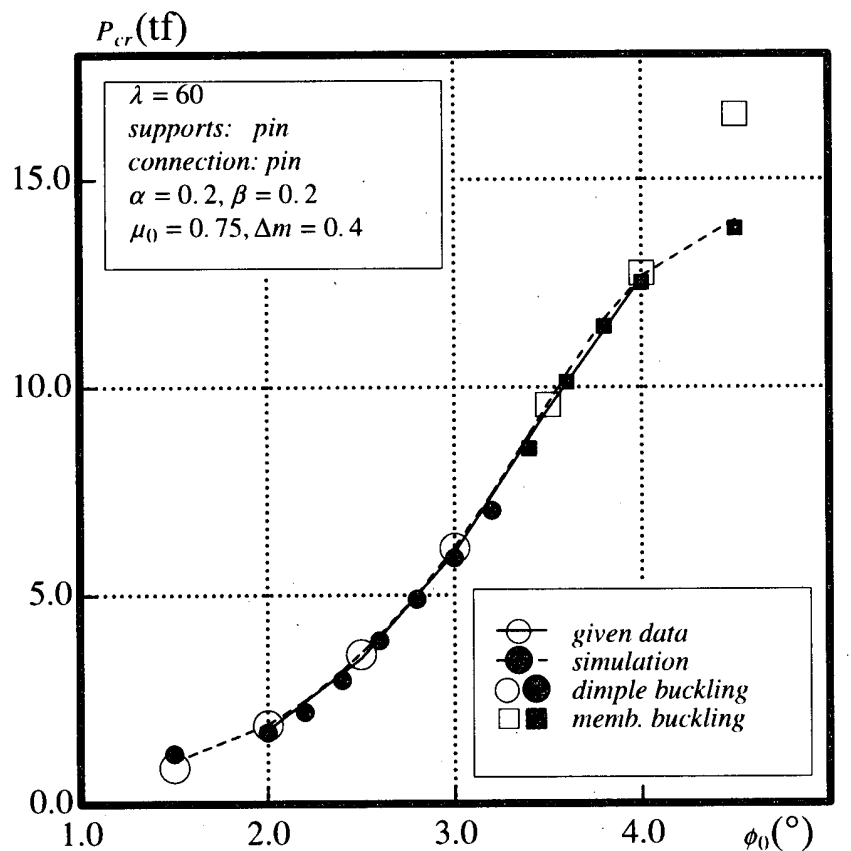

図ー 6 ピン支持・ピン接合ドームのP $\mathrm{cr}-\phi_{01}$ 関係

NNに模擬させたデータ以外の入力に対する予測精度は NNの構 成上の各種パラメータとノードの出力関数に依存することは前章 でも述べた。取り扱うデータが増加した場合，それらの性質がど のように変化するのかを本章では分析することとする。

\section{1 .2 作成した NNの精度}

あらかじめ教師データとして与える，ドームの形状パターンの 組合せを図一 4 内に合わせて揭載する。これらを精度良く再現で きればデータベースシステムとして利用可能なNNを構築できた こととなる。しかしながら，NNでは滑らかな多変数高次関数で 内挿が可能となることから，その能力も発揮できるよう，与えら

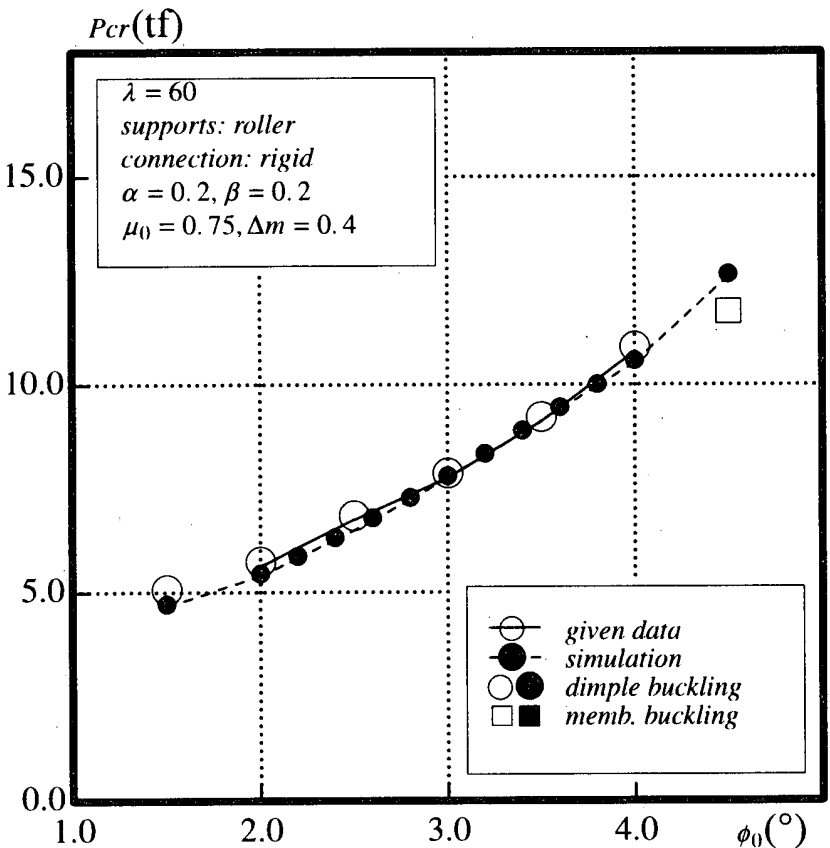

図ー7 ローラー支持・剛接合ドームの $P\left(r-\phi_{0}\right.$ 関係

れたデータに対して座屈荷重, タイプを応答するだけでなく，2 章同様，ある程度の補間能力を持つネットワーク作成を目指し た。NNの層数, 節点数, 収束パラメー夕を試行錯誤的に変化さ せ, 中間層が 2 層で各々に入力層のノード数と同じ 6 個のノード を持つ形状が最も小さな誤差に収束することを確認した。しかし ながら, 他のパラメータ, 形状の組合せてより適切なものが発見 される可能性は残る。尚, 単位ドームに対するNNにはスパン数 図一 5 内の上から7番目に示している入力デー夕)は与えていな い。そのシステムの精度を確認するために, ドームの部材半交角 と座屈荷重の関係をグラフ化したものが図一 6,7 である。 


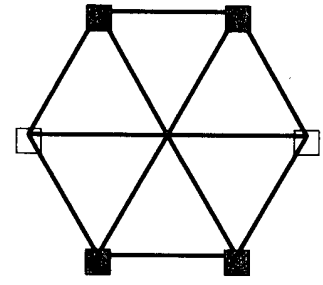

FEM: $P_{c r}=3.77 t f$

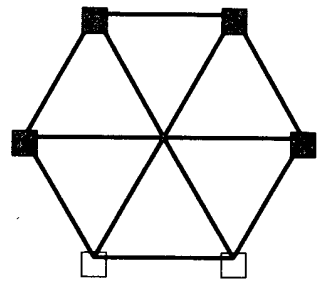

$P_{c r}=3.93 t f$

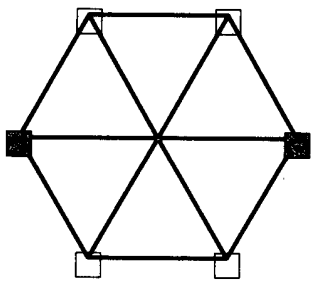

FEM: $P_{c r}=3.01 t f$

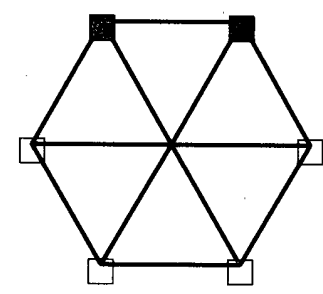

$P_{c r}=3.13 t f$

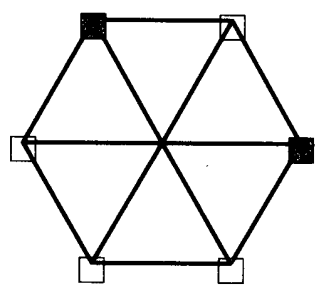

$P_{c r}=2.99 t f$

NEURON: $P_{c r}=3.94 t f(\mathrm{~B}=2 / 3)$

a) 4 nodes supported as pin on the boundary

NEURON: $P_{c r}=3.05 t f(\mathrm{~B}=1 / 3)$

b) 2 nodes supported as pin on the boundary

図ー8 境界条件に伴うF EMとニューロンの符合（回：ピン, $\square:$ ローラー）

表 -2 内挿性の検討(FEMとNNの結果比較)

\begin{tabular}{|c||c|c|c|}
\hline$\phi_{0}{ }^{\circ}$ & method & $P_{c r}(\mathrm{tf})$ & buckling type \\
\hline \hline 3.2 & analysis & 7.35 & 1.0 \\
& neural network & $\mathbf{7 . 4 4}$ & $\mathbf{0 . 6 2 1 4}$ \\
\hline \multirow{2}{*}{3.4} & analysis & 8.85 & 0.0 \\
& neural network & $\mathbf{8 . 8 7}$ & $\mathbf{0 . 0 2 9 4}$ \\
\hline \multirow{2}{*}{3.6} & analysis & 10.27 & 0.0 \\
& neural network & $\mathbf{1 0 . 3 3}$ & $\mathbf{0 . 0 0 1 4}$ \\
\hline \multirow{2}{*}{3.8} & analysis & 11.49 & 0.0 \\
& neural network & 11.64 & $\mathbf{0 . 0 0 0 2}$ \\
\hline
\end{tabular}

ここで, $2.0 \leq \phi_{0}<4.0$ の範囲における○あるいは口が教師データ を表し， $\phi_{0}<2.0, \phi_{0}>4.0$ の範囲におけるそれらは教師デー夕と して採用されていない弾塑性解析結果のプロットである。一方,

○、覀はNNの排出したデータを表わす。

図ー6，7 見ることで多パラメータの入力にも倸わらず，内挿 については精度良い関数あるいはシステムを実現出来ている。入力 パラメータがピン支持, ローラー支持と変化しても, 内挿式の形が 柔軟に変化できていることが双方の図の比較から理解できる。ま た, 表一 2 で部材半交角が3.2〜3.8度に対する教師データが存在し ない範囲での内挿性を検討している。弾塑性解析結果と比較すると 座屈荷重はNNの予測值が 1 ～ $2 \%$ 程度大きめとなるが, 問題視すべ き量ではないと考えられる。また, 座屈タイプも適切に対応出来て いることが判る。

一方，外挿性については，図ー6，7に示すようにピン支持・ピ ン接合, ローラー支持・剛接合で実際の解析結果との差異が確認で き, 十分な能力は得られていない範囲がある。入出力デー夕の正規 化を sigmoid関数のどの位置をNNに反映させるかいう点まで念頭に 入れて初期から NN構築を行う必要があると考えられる。しかしな がら, 学習範囲のパラメータを越える部分を目標値なしに予め形を 想定しておくことは, 通常困難と考えられる。今回目的としている エキスパートシステム内の推論エンジンへの適用を考える際には,

内挿性能が確保できれば実用上問題はないと考えるが, 外挿部分に ついてはその性能が要求される問題である場合, 再度分析・検討を 要するものと思われる。

図ー8には, 境界条件を変化させた場合のネットワークの内挿性
能を確認した結果を示す。Bは全節点がピン支持なら1，ローラー 支持なら 0 となる拘束パラメータである。中間的な境界条件であっ ても比較的精度良く座屈荷重が表現できている。図中, NNの出力 は 1 つになっているが, 支持点の挿入場所に関する情報を NNに与 えていないため, あるパラメータBに対して1つの応答を返すシス テムが採用されているためである。更にきめ細かな入力パラメータ を想定し検討を進めることも今後の課題の一つである。

3.24 スパンドームのデータを付加した場合

3.2 .1 対象と目的

この種のシステムでは学習させたい事項の増加が予想され，それ に柔軟に対応できるかどうかもシステム構築上の重要な要素と言え る。学習するデータが増加し, 更に入力データにスパン数を加え, 入力パラメータ数も増加した場合のネットワークの再構成を行う。

そこで, 図ー4の太い破線部分が周辺部材となるような, ドーム の稜線が 4 本の部材で構成される，4 スパンドームのデータを加え たNN構築を試みる。ドームの載荷重は各節点に鈶直方向等分布に 作用している。単位ドームのみの場合, 中間層を 2 層用意すること で, データの再現性, 補間能力共に確保できたが, 4 スパンドーム のデータを含めた場合も試行的に中間層数は 2 とした(各パラメー 夕の試行錯誤的な決定方法は例として，付録に示している)。

ノード数を変化させ，50,000回の後方伝播のステップを踏ませ， 得られたエラー値から, 図ー5のような出力ノードに向かって中間 層のノード数が隇少していく形状のネットワークを採用した。これ は, 更にスパン数, 平面形状の異なるドームのデータを学習してい く上で, ネットワークの形態の変化を余儀なくされることを示唆 し, 知識ベース作成において, ネットワークの形状発見問題は重要 課題の一つとなる。

3.2.2 デー夕再現性と補間能力

図－9 a ），b）では, 各々, ピン支持剛接合ドームとローラー 支持ピン接合ドームを取り上げた場合の教師データとNNから得ら れた值の対比を, 部材半交角 $\phi_{0}$, ならびにスパン数 $n$ を平面軸 に, 縦軸に弾塑性座屈荷重 $P_{c r}$ を取って表現している。図中白抜 きマークが与データであり, 塗り潰しマークがNN から得られた結 果である。また，座屈形式に対する記号表現において，（）内に示 される数值は形式分類のために実際にNNに与えた值である。いず れの図からも，NNが教師データを比較的精度良く再現しているこ とが判る。 


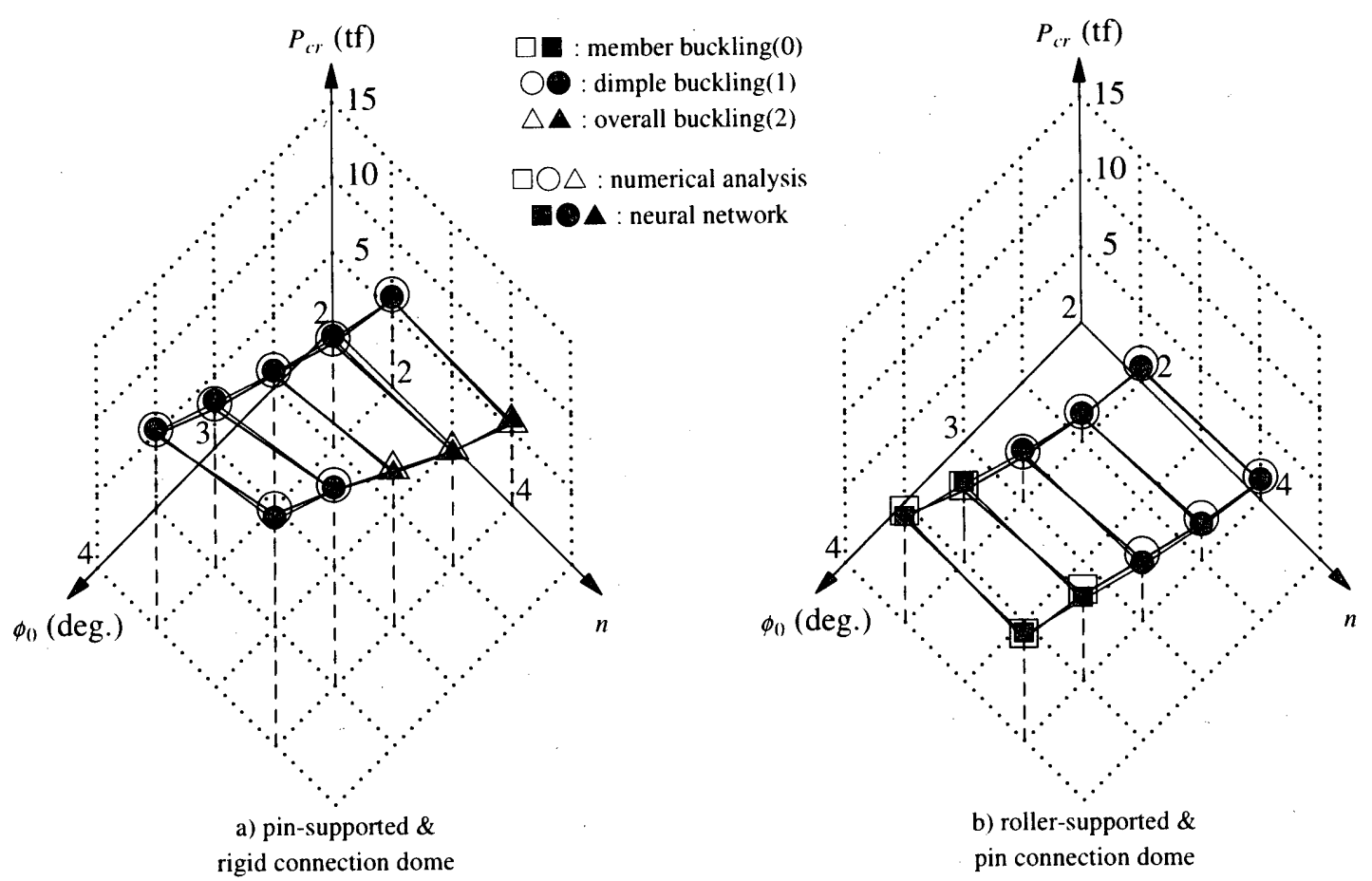

図ー $9 n=2 か ゙$ 加わった場合のデータの再現性

表 -3 内挿性の検討 (b.t. = buckling type $)$

ピン接合ピン支持単位ドームを対象とした例

\begin{tabular}{|c||c|c||c|c||c|}
\hline \multicolumn{3}{|c||}{ analysis } & \multicolumn{3}{c|}{ neural network } \\
\hline$\phi_{0}{ }^{\circ}$ & $P_{c r}(\mathrm{tf})$ & b.t. & $P_{c r}(\mathrm{tf})$ & b.t. & given/not \\
\hline \hline 3.0 & 6.01 & 1 & 6.09 & 1.00 & given \\
3.2 & 7.35 & 1 & 7.32 & 0.95 & not \\
3.4 & 8.85 & 0 & 8.69 & 0.07 & not \\
3.5 & 9.46 & 0 & 9.35 & 0.02 & given \\
3.6 & 10.27 & 0 & 9.85 & 0.44 & not \\
3.8 & 11.49 & 0 & 11.03 & 0.32 & not \\
4.0. & 12.64 & 0 & 12.41 & 0.00 & given \\
\hline
\end{tabular}

表ー3にはNNの補間能力を更に精細に検証するために, ピン支 持ピン接合単位ドームの座屈荷重と座屈形式を対象に, 弾塑性解析 結果とNNの出力の比較を纏めている。座屈形式の数值の意味は図 - 9 にあるように, 0 が部材座屈を, 1 がディンプル座屈を表わ す。ほぼ，内挿性も確保できていると判断できる結果ではあるが， 単位ドームのみを対象としたNNにおける再現性・内挿性に較べる といずれも精度はやや少化している。これは, 単位ドームを対象と したNNが 5 万回程度の収束計算を行ったのに対して, その10倍程 度の収束計算を許容したにも係わらず，エラー值が収束基準を十分 にクリアできなかった点にも依存していると考えられる。しかしな がら, 学習データが増えることによって, 排出エラー量が増加傾向 に入ることはやむを得ないこととも言える。

表一 4 には 4 スパンドームのデー夕を加えた場合のNNのエラー 総量と再現座屈荷重の関係を示している。n泣パン数の半分で1 が単位ドームを，2が4スパンドームを表す。ここで, エラ一総量 は, 出力ノードの出力值 $y_{j}$ と教師データ $T_{j}$ の差で式(4)のように計 算できる。同表では例として $E=0.01$ と $E=0.001$ の場合を比較し
表ー 4 エラー総量と再現座屈荷重(tf)の関係

剛接合ピン支持ドームを対象とした例

\begin{tabular}{|c||c|c|c|c|}
\hline$\phi_{0}{ }^{\circ}$ & $\mathrm{n}$ & analysis & $E=0.01$ & $E=0.001$ \\
\hline \hline 2.0 & 1 & 5.86 & 6.15 & 5.83 \\
& 2 & 5.45 & 5.36 & 5.49 \\
\hline 2.5 & 1 & 6.96 & 7.16 & 6.99 \\
& 2 & 7.66 & 7.85 & 7.70 \\
\hline 3.0 & 1 & 8.89 & 8.70 & 8.88 \\
& 2 & 10.38 & 10.21 & 10.40 \\
\hline 3.5 & 1 & 10.63 & 10.60 & 10.71 \\
& 2 & 13.13 & 13.30 & 13.17 \\
\hline \multirow{2}{*}{4.0} & 1 & 12.91 & 12.81 & 12.91 \\
& 2 & 15.53 & 15.56 & 15.54 \\
\hline
\end{tabular}

ている。Eの值が 10 倍の差を持つことで, 最大 $5 \%$ 程度の内捚性能 の差異が生じる。この数值の開き自体を重要視しなくて良い対象問 題については排出されるエラ一值に厳しく敏感である必要はないと も言える。また，スパン数nは20によって正規化されているが，こ れは最大 $n=20$ 程度のドーム迄を学習対象として想定しているため である。正規化の分母を10,20と変化させた場合, 50,000回の収束 計算後のEの值は $10^{-4}$ 程度の差異しかなく, 出力にも殆ど変化が現 れなかった。今回扱った $\mathrm{n}=2 \sim 4 の$ 範囲ではnが正規化に敏感ではな かったと言えるが， $\mathrm{n}$ 範囲を更に広げた上で他の正規化パラメー タと共に検討した結果は次報に取り上げる予定である。

さて, 推論エンジン化に向けては,

(1) 推論の適用範囲を明示した上でエキスパートシステム内に組み 込む場合はその内挿能力を更に慎重に検討していくことが必要 であり， 
(2) 外挿能力を見出せるNNを模索することで，エキスパートシステ ムの汎用性を上げることが可能になり，NNの更に多様な問題へ の適用性を見出すことにもつながる，

と考える。しかしながら, 項目(1)を重視したシステムの方が実用 上安定するであろうことをここで付記しておく。

\section{4. 缠めと今後の問題点}

単材の座屈曲線, 及び, 単層ラチスドームの弾塑性座屈荷重, 座 屈タイプを対象として, 多パラメータ下におけるそれらのデータベ 一ス化，あるいは推論エンジン化にNNを用いた試行から，以下に 挙げる項目を確認できた。

(1) 目的となるデータ並びが入力パラメータに対して比較的起伏の 小さな非線形関係である場合, 精度良くデー夕を再現出来る。

(2) 例えば入力パラメータ 1 つに対して, 出力が 1 つに対応するよ うな入出力の関係に複雑性が少ない問題に対しては, NN構築の 試行計算過程のコストも小さく，また適切なNNが比較的簡易に 得られる。

(3) 単層ラチスドームを対象とした入力パラメータ 7 個, 出力が 2 個になるような多パラメータの組合せが存在するシステムにも 教師デー夕群を補間できる能力を有するNNが発見できた。これ により，エキスパートシステムの推論エンジンへのNNの適用可 能性を確認できた。

(4) 教師データを補間する能力は適切なNNの計算パラメータ, 形状 を決定することに依存する。

また，問題点と今後の展望として，箇条書きにすると，

(1) NNのパラメータを試行錯誤的に決めていては複雑な問題を対象 とする場合に適切なNNに辿り着けない可能性がある。それを解 消する手法を模索する必要がある。既に AIC ${ }^{24)}$ (Akaike Information Criterion)を用いたネットワークサイズの最適化を図る手法 が報告されている ${ }^{25)}$ が, 最終的にはNNの挙動を再確認する必 要はある。これらに加えて, 既に実行中であるGAによる最適値 挆索によって解決出来るかを別機会に纏める予定である。

(2) より早く適切に教師データを反映出来, 学習する方法(例えば文 献26)のアンサンブル学習等)を模索することも必要となろう。

(3) NN自体の持っている特性, あるいは新たなアルゴリズム(例え ば文献4) 等による最新情報)を更に精査・分析し, データベース だけでなくエキスパートシステムの推論エンジンとしての信頼 性を獲得する背景を築く。

\section{謝辞}

本研究を開始する段階で, 有益な示唆を戴いた豊橋技術科学大 学・加藤史郎博士へ深く感謝の意を表します。また, 数值計算デー 夕の蓄積には飯田稔氏(元豊橋技術科学大学・工学専攻科)の多大な 協力を戴いた。ここに感謝の意を表します。

\section{参考文献}

1）日本建築学会情報システム技術委員会, 第26回情報・システム・利用・技 術シンポジウム論文集, 2003.12

2) Hassoun.M.H.: Fundamentals of ARTIFICIAL NEURAL NETWORKS, The MIT Press, 1995

3) Anderson,J.A.: An Introduction to Neural Networks, The MIT Press, 1995
4) Jordan,M.. Kearns, M. and Solla,S.: ADVANCES IN NEURAL INFORMATION PROCESSING SYSTEMS 14, The MIT Press, 2001

5) Rosenblatt.F.: Principles of Neurodynamics, Spartan, Washington, DC, 1961

6) Minsky,M., Papert,S.: Perceptrons. Cambridge, MA: MIT Press., 1969

7) Rumelhart,D.E., Hinton,G.E.. Williams,R.J.: Learning representations by backpropagating errors NATURE,No.9,Vol.323, pp.533-536, 1986.10

8) 麻生英樹: ニューラルネットワーク情報処理, 産業図書, pp.14-37, 1988

9) Ghaboussi,J., Garrett,J.H.. Wu.X.: Knowledge-Based Modeling of Material Behavior with Neural Networks J. Engrg. Mech. Div., ASCE No.117-1, pp.132-153, 1991

10) Yoshimura,S., Yagawa,G., Toyonaga,K., Ohishi,T., Mochizuki,Y.: Structural Identification by means of the Combination of Neural Network and Computational Mechanics -Its Application to One-Dimensional Beam- TRANSACTIONS OF THE JAPAN SOCIETY OF MECHANICAL ENGINEERS Vol.58, No.550, pp.1689-1695, 1992.6

11) 堤和敏, 河村廣, 谷明勲: ニューラルネットワークを利用した平均建物重 量推定システムの研究, 日本建築学会構造系論文集, No.458, pp.171-177, 1994.4

12) 谷明勲, 河村廣: 階層型ニューラルネットワークおよびファジィ理論を用 いた建築構造物の最適適応予測制御システム, 日本建築学会構造系論文 集, No.458, pp.179-189, 1994.4

13) 水野啓示朗, 松井徹哉: ニューラルネットワークによる構造物の振動応答 推定, 日本建築学会構造系論文集, No.503, pp. 53-60, 1998.1

14) 楊元植, 中埜良昭, 楠浩一: ニューラルネットワークによる履歴推定手法 を用いたオンライン地震応答実験に関する研究一その 2 , 日本建築学会学 術講演梗概集（中国），構造 I (B-1),pp.411-412, 1999.9

15) 神田克久: ニューラルネットワークによる自己学習機能を持った地震早期 検知システムの研究, 日本建築学会構造系論文集, No.498, pp.59-66, 1997.8

16) 堤和敏，南川吉孝: ニューラルネットワークを利用した鉄骨造弾性骨組の 層間変形角制約設計、日本建築学会構造系論文集、No.472, pp.193-199, 1995.6

17) 堤和敏, 河村廣, 谷明勲: ニューラルネットワークを利用した「設計ノウ ハウ」のシステム化に関する研究、日本建築学会構造系論文集, No.473, pp.207-215, 1995.7

18) 堤和敏: ニューラルネットワークを利用した鉄骨造弾性立体骨組の性能指 定最小重量設計法, 日本建築学会構造系論文集, No.496, pp.137-141, 1997.6

19) 井原孝志, 水野啓示朗, 福田隆介, 松井徹哉: 構造物の履歴挙動のモデリ ングに用いるニューラルネットワークの学習方法に関する研究, 日本建築 学会学術講演梗概集（九州）、構造 I (B-1), pp.445-448, 1998.9

20) 堤和敏, 薦野和彦, 加藤泰夫, 安藤欽也, 倉島重夫, 赤星靖, 吉田聡: S 系一質点系弾塑性モデルの履歴エネルギ一係数同定による応答変形推定 法.第 22 回情報・システム・利用・技術シンポジウム論文集, pp.31-36, 1999.12

21) 加藤史郎, 高島英幸：6 角形平面の剛接単層ラチスドームの弾塑性座屈解 析-形状初期不整が存在しない完全形状ドームについて-, 日本建築学会構 造系論文報告集, No.408,pp.77-87, 1990.2

22) Takashima,H. \& Kato,S.: CONCEPTS TO CREATE DATA-BASE/REASONING SYSTEM FOR SPACE DOME BUCKLING BASED ON NEURAL NETWORK, Spatial Structures: Heritage, Present and Future, IASS International Symposium 1995 - Milano, vol.1, pp.119-126, 1995.6

23) 高島英幸:ニューラルネットワークを用いた単層ラチスドームのシステム 同定とエキスパートシステムへの適用性, 第18回情報・シスデム・利用・ 技術シンポジウム論文集, pp.409-414, 1995.12

24) H. Akaike: A new look at the statistical model identification. IEEE Trans. on Automatic Control, Vol. 19, No. 6, pp. 716-723, 1974.

25) N. Murata, S. Yoshizawa, and S. Ámari.: Network information criterions -- determining the number of parameters for an artificial neural network model, IEEE Trans. on Neural Networks, Vol. 5, pp. 865-872, 1994.

26) 内海金太郎, 堤和敏:アンサンブル学習を適用した街並み評価システムの 学習デー夕選定に関する研究, 日本建築学会学術講演梗概集(東海),防火. 海洋・情報システム技術(A-2), pp.547-548, 2003.9 
注

注1)補間関数を sigmoid関数からリニア，バイリニア関数等へ変更することも 可能だが，今回対象とした問題では却って内摷性を損なうことになり， 実際に適用し，検討を行った結果、このような考察とした。

\section{付録}

3.2節で提示した4スパンドームに対するNNを作成するあたり、NNを構成 するための適切と思われるパラメー夕を試行錯誤的に求めている。その一部 をここに提示し, 本研究で対象とした事象が各パラメータに対してどのよう な敏感度を有しているのかを述べておく。

各図内のEは式(4)で示したエラー総量で50,000回の収束計算を行った後の 値である。また, 注目しているパラメー夕以外のものも同様に変動させてい く必要があるが, ここでは, 中間層数を 2 , その各々の中間層の節点数を 6 ,

4, $\alpha=\beta=0.4 . \Delta m=0.4, \mu_{0}=0.75$ を基本パターンとして, 注目していな いパラメータを設定している。

図ーAは、NNの中間層の数とその節点数を変化させた場合のEの変動を表 している。2層分設定した方が収束性能が良いことが判る。2層分の節点数を 各々6，4としたところで収束性能に頭打ちが観察されたので，本論文内で は，中間層を 2 , 各々の節点数を 6,4 と設定した。図一Bを観ると， sigmoid 関数の傾き $\mu_{0}$ に関しては $0.75 \sim 0.80$ 辺りでエラー総量が最小となっている。 収束計算時の結合係数，あるいはオフセットに関する增分量， $\alpha, \beta$ は, 図一Cから，双方とも0.2 0.4の値を取ることでエラー総量の収束性能が良 いと判断できた。また，図ーDには，加速度係数 $\Delta m$ を変化させた場合のエラ 一総量の差異が示されているが，Eの絶対量自体が左程大きくなく，他のパ ラメータに較べれば敏感度がやや劣化しているが, 本システムではギャップ の見られた $\Delta m=0.4$ を採用した。
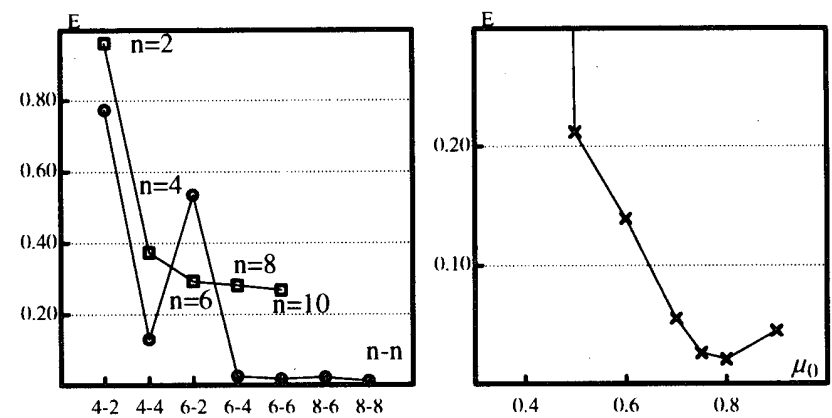

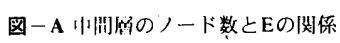

图一B sigmoid闺数の倬きとEの関係

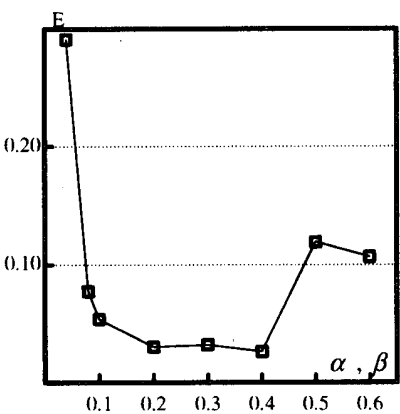

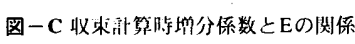

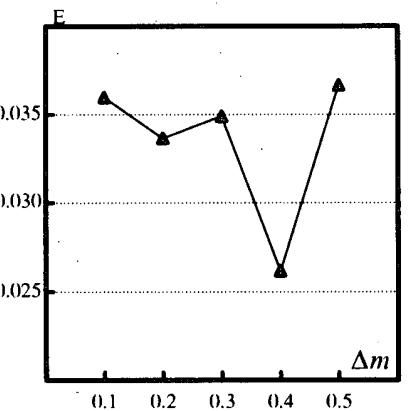

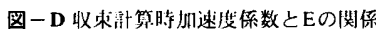

（2004年 2 月 10 日原稿受理，2004年 8 月 26 日採用決定） 